\title{
Different Intestinal Microbiota Composition Inhibits the Lactobacillus Growth in Rheumatoid Arthritis Patients in Malang, Indonesia
}

\author{
Mufidah Mufidah ${ }^{1,3}$, Eko Suyanto ${ }^{1,3}$, Viranda Susanti ${ }^{2,3}$, Hazna Noor Meidinna ${ }^{1,3}$, Fatchiyah \\ Fatchiyah $^{1,3^{*}}$ \\ ${ }^{1}$ Department of Biology, Faculty of Mathematics and Natural Sciences, Brawijaya University, Malang, Indonesia \\ ${ }^{2}$ Faculty of Dentistry, Brawijaya University, Malang, Indonesia \\ ${ }^{3}$ Research Center of Smart Molecule of Natural Genetics Resource, Brawijaya University, Malang, Indonesia
}

\begin{abstract}
Rheumatoid arthritis (RA) is an autoimmune disease that can cause progressive damage to the joints of patients. The number of patients is expected to increase, along with the exact cause of this disease remains unknown. However, there are several risk factors associated with RA, including dysbiosis. The purpose of this study was to characterize the composition of intestinal microbiota in the RA and control groups through fecal analysis and reveal the association of microbiota composition with RA disease in Indonesia, especially Malang. Fecal samples were obtained from RA patients and controls. Fecal analysis was carried out through several stages, namely the calculation of total bacterial colonies, isolation and characterization of anaerobic bacteria, calculation of the Simpson diversity index, and DNA isolation. Analysis of bacterial composition profiles in fecal was carried out using 6 specific primer sets through PCR analysis. The results of the $16 \mathrm{~S}$ rRNA PCR analysis showed different microbiota compositions between RA patients and controls. The number of Enterococcus bacterial group was lower in the control patients than the RA group, whereas the Lactobacillus bacteria decreased in RA patients. In addition, our study found that the existence of bacterial isolate 11 changed the composition of microbiota in RA patients, and the DNA band only appeared in Universal primers. The diversity of bacterial species can provide symbiotic and pathogenetic effects in RA patients.
\end{abstract}

Keywords: Dysbiosis, intestinal microbiota, PCR, rheumatoid arthritis.

\section{INTRODUCTION}

Rheumatoid arthritis (RA) is an autoimmune disease in humans, which is characterized by metabolic disorders and damage to several joints [1]. This disease has received serious attention in Indonesia since the prevalence increased from $6.12 \%$ in 2013 [2] to $11.9 \%$ in 2018 [3]. The exact cause of RA disease is still unknown hitherto. This phenomenon is caused by RA including in group of multifactor disease. Therefore, the incidence of RA is expected to increase continously.

Previous studies have reported that several factors increase the risk of RA, including age, sex, ethnicity, genetics, and environment [4]. One factor that has been a concern of researchers is the relationship between the emergence of this disease with abnormalities of microbiota (dysbiosis) in the intestinal tract. Dysbiosis may be involved with RA pathogenicity [5]. The condition of dysbiosis in the human digestive tract causes changes in the lining of the intestinal epithelial cells leading to inflammation [6].

Inflammation can trigger the synovial tissue of the joints to form pannus tissue. Pannus tissue will invade bone resulting in damage to the

\footnotetext{
*Correspondence address:

Prof. Dra. Fatchiyah, M.Kes., Ph.D

Email : fatchiya@ub.ac.id

Address : Faculty of Mathematics and Natural Sciences, Brawijaya University, Veteran Malang, 65145
}

cartilage in the joints [7]. Synovial tissue inflammation can be initiated by several factors, namely immunological and microbial disorders, including oral bacterial DNA in the mouth, increased expression of the peptidylarginine deiminase (PAD) enzyme, unmethylated CpG oligonucleotide, and lipopolysaccharide in bacterial membranes [8].

The human digestive tract contains an abundant and diverse microbial community. Bacterial abundance in the digestive tract is estimated to reach $10^{11}$ to $10^{12}$ per-milliliter [9]. In normal condition, the dominant intestinal microbiota originates from the phyla Firmicutes, Bacteroidetes, Actinobacteria, and Verrucomicrobia [10]. Besides being involved in the digestion and absorption of food, bacteria are also known to be involved in the modulation of the immune system [11-13]. Previous studies have reported changes in the composition of microbiota in the intestine with the immune system lead to autoimmune diseases, which is rheumatoid arthritis [14].

The intestinal microbiota composition of RA patients and controls showed a difference, wherein RA patients, there was a reduction of certain bacteria in the Bifidobacterium and Bacteroides family [15]. Other studies showed the increase of Lactobacillus salivarius species in RA [16]. However, the correlation of the 
intestinal microbiota composition in affecting the development of RA in humans is still unclear due to various factors of the disease. Therefore, this study was conducted to characterize the composition of intestinal microbiota in RA and control (Non-RA) patients in Indonesia, especially Malang city, through fecal bacteria analysis based on 16S rRNA using PCR. Fecal bacterial analysis can describe the microbial community in the intestine that initiates the emergence of disease in humans because it is related to the fact that fecal is the final product of the digestive process that occurs in the intestine [17]. This research is expected to reveal new things about the composition of microbiota in the intestines of RA sufferers in Indonesia.

\section{MATERIAL AND METHOD}

\section{Ethics Clearance}

This study was approved with the code of ethics (ethical clearance) No. 051/EC/KEPK-FKIK/ 2019 by the Health Research Ethics Commission (KEPK) Faculty of Medicine and Health Sciences UIN Maulana Malik Ibrahim Malang.

\section{Sampling}

Fecal samples were obtained from the hospital with a doctor's intermediary. Patients were recruited based on the sampling method after obtaining an explanation and agreement through the signing of informed consent. Fecal samples were divided into two groups, namely the control (non-RA) and RA group, which consists of three patients as replicates in each. Recruitment of patients as control (Non-RA) and RA group was based on medical records from the hospital with several inclusion criteria of not taking antibiotics, not consuming yogurt during the last four weeks before sampling, and having Indonesian citizenship based on an identity card. Fecal sampling was done by giving patients a sterile set of sampling equipment. Furthermore, fecal samples were stored at $4^{\circ} \mathrm{C}$ for further analysis [18].

\footnotetext{
Culture and Determination of Aerobic Mesophilic Bacteria

The 0.5 grams of fecal samples from each patient were collected and then put into $\mathrm{NaCl}$ $0.9 \%$ using the serial dilution technique. Dilution was carried out to the desired concentration. The suspension was cultured in plate count agar (PCA) media and then aerobically incubated at $37^{\circ} \mathrm{C}$ for 48 hours. The aerobic bacterial colonies were counted using a colony counter. The calculation was established in triplicate for each control (Non-RA) and the RA group.
}

\section{Isolation and Characterization of Anaerobic Bacteria}

Anaerobic bacterial isolation was done using the serial dilution technique with peptone yeast glucose (PYG) agar. A diluted sample solution of $0.1 \mathrm{~mL}$ was put into a sterile petri dish using the pour plate technique and then incubated in the anaerobic jar at room temperature for 48 hours. Anaerobic bacterial colonies were counted and observed for the morphological characteristics. They were purified using the four-way streak plate technique until the pure culture was obtained.

\section{Simpson index calculation}

The diversity index used in this study was the Simpson index. The total number of colonies and the number of different species' colonies found in each sample were calculated. The data obtained were analyzed using the Id formula [19]. The Simpson diversity index ranged from 0 to 1 . Id values could be calculated using the following formula [20]:

$$
I d=\frac{\sum N i(N i-1)}{N(N-1)}
$$

Description:

Id = Diversity index

$\mathrm{Ni}=$ Number of specific individuals / species found

$\mathrm{N}=$ Total number of individuals found

The representation of the index value is as follows:

$0.00-0.3=$ Low dominance, high diversity

$0.31-0.6=$ Moderate dominance, moderate diversity

$0.61-1.0=$ High dominance, low diversity

\section{Bacterial DNA isolation}

Anaerobic bacteria were grown in $3 \mathrm{~mL}$ of Luria Bertani (LB) broth media for 16 hours at $37^{\circ} \mathrm{C}$. Bacterial culture in LB media was centrifuged at $10,000 \mathrm{rpm}, 25^{\circ} \mathrm{C}$ for 5 minutes. The pellets obtained were added with buffer lysis (25 mM EDTA pH 8, 10 mM Tris- $\mathrm{HCl}$ pH 8, 100 $\mathrm{mM} \mathrm{NaCl}, 1 \%$ SDS, $5 \mathrm{mg} \cdot \mathrm{mL}^{-1}$ proteinase-K, and distilled water) and then incubated at $37^{\circ} \mathrm{C}$ for an hour. Furthermore, the isolation steps of anaerobic bacterial DNA in fecal samples followed the previous method with several modifications [21]. The obtained DNA was stored at $-20^{\circ} \mathrm{C}$ until used.

\section{Bacterial DNA amplification}

The PCR technique was based on the previous method with several modifications [21]. The PCR was performed using a thermal cycler with the PCR program set up as follows: hot start at $95^{\circ} \mathrm{C}$ for 3 minutes; 31 cycles of denaturation at $95^{\circ} \mathrm{C}$ for 30 seconds, annealing at $55^{\circ} \mathrm{C}$ for 30 seconds, extension at $72^{\circ} \mathrm{C}$ for 1 minute; and post 
extension at $72^{\circ} \mathrm{C}$ for 5 minutes. Primers used for amplifying the DNA of digestive tract bacteria were the primary set of Universal, Bacteroides, Clostridium, Bifidobacterium, Enterococcus, and Lactobacillus (Table 1) [22]. The amplification results were detected using $1.5 \%$ agarose gel and visualized using the UVP Biodoc-IT Imaging System.

Table 1. Primers used in bacterial DNA amplification

\begin{tabular}{lll}
\hline Primer & Primer sequences (5'-3') & Ref \\
\hline Uni-F & TACGGGAGGCAGCAG & 23,24 \\
Uni-R & ATTAACCGCGGCTGCTGG & \\
g-Bifid F & CTCCTGGAAACGGGTGG & 23 \\
g-Bifid R- & GGTGTTCTTCCCGATATCTACA & \\
Ent.1017F & CCTTTGACCACTCTAGAG & 23 \\
Ent.1263R- & CTTAGCCTCGCGACT & \\
Lac1-F & AGCAGTAGGGAATCTTCCA & 23 \\
Lac2-R & ATTYCACCGCTACACATG & \\
Bact_F & TCAGTTGTGAAAGTTTGCG & 23 \\
Bact_R- & GTRTATCGCMAACAGCGA & \\
Ccoc_F & TGACGGTACCTGACTAA & 24 \\
Ccoc_R- & CTTTGAGTTTYATTCTTGCGAA & \\
\hline
\end{tabular}

Source: Scientific jounnal [22]

\section{Statistical data analysis}

Data were analyzed through descriptive statistics using Microsoft Excel and one-way ANOVA using SPSS 16.0 for windows. Statistical tests performed normality and homogeneity tests with a significance level of $5 \%(p<0.05)$.

\section{RESULT AND DISCUSSION}

The Amount of Aerobic Mesophilic Microbiota in the Fecal Samples of Control and RA Patients

The aerobic mesophilic count (AMC) performed in three control groups and three RA patients showed differences. The calculation results on Control C1, C2, and C3 were $0.84 \times 10^{8}$ $\pm 0.34,43800 \times 10^{8} \pm 4.79$, and $2.58 \times 10^{8} \pm 0.10$, respectively (Table 2 ). This value indicated that the amount of AMC of $C 2$ was higher than that of C1 and C3. AMC values of RA patients RA1, RA2 and RA3 were $550 \times 10^{8} \pm 0.23,8.13 \times 10^{8} \pm 0.36$ and $0.37 \times 10^{8} \pm 0.04$, respectively.

Table 2. Aerobic mesophilic count of bacterial colonies in control and RA patients

\begin{tabular}{ccll}
\hline \multirow{2}{*}{ No } & \multirow{2}{*}{ Sample } & \multicolumn{2}{c}{ Total bacteria $\left(\mathbf{1 0} \mathbf{~ 1 0} \mathbf{C F U}_{\mathbf{m}} \mathbf{m}^{-\mathbf{1}}\right)$} \\
\cline { 3 - 4 } & & \multicolumn{1}{c}{$\mathbf{P}<\mathbf{0 . 0 1}$} & $\mathbf{P}<\mathbf{0 . 0 5}$ \\
\hline 1 & C1 & $0.84 \pm 0.34^{\mathrm{ab}}$ & $0.84 \pm 0.34^{\mathrm{a}}$ \\
2 & C2 & $43800 \pm 4.79^{\mathrm{abc}}$ & $43800 \pm 4.79^{\mathrm{abcd}}$ \\
3 & C3 & $2.58 \pm 0.10^{\mathrm{ab}}$ & $2.58 \pm 0.10^{\mathrm{b}}$ \\
4 & RA1 & $550 \pm 0.23^{\mathrm{abc}}$ & $550 \pm 0.23^{\mathrm{c}}$ \\
5 & RA2 & $8.13 \pm 0.36^{\mathrm{cd}}$ & $8.13 \pm 0.36^{\mathrm{d}}$ \\
6 & RA3 & $0.37 \pm 0.04^{\mathrm{bc}}$ & $0.37 \pm 0.04^{\mathrm{a}}$ \\
\hline
\end{tabular}

Notes: Values indicate the mean \pm standard deviation. Values with the same notation in the column do not differ significantly ( $p<0.01$ and $p<0.05$ ).
The RA1 had a higher AMC value than that of RA2 and RA3. The AMC value of $C 1$ was significantly lower than RA2 $(p<0.01)$. There were no significant differences between C2, C3, RA1, and RA3. However, the AMC values of $\mathrm{C} 1$, C3, RA1, RA2, and RA3 showed significant differences with a significance level of $5 \%$ ( $p$ $<0.05$ ) (Table 2).

\section{Morphological Characters and Diversity of Microbiota}

The most abundant type of microbes found in the human digestive tract was anaerobic bacteria. Previous data reported that the total number of bacteria in each individual's fecal sample consisted of aerobic and anaerobic bacteria. The results of anaerobic bacterial isolation showed the presence of bacterial colonies with 30 different morphological characters. Morphological characters observed included shape, configuration, elevation, optical characteristics, texture, and color. A total of 30 isolates were screened representing each group until eight selected isolates were obtained. The selection was based on characters, including the bacterial isolates found in the control group and RA, found only in the control group, and found only in the RA group (Fig. 1, Table 3).

Our study reported differences in bacterial composition in RA and control patients. The data were used to analyze the diversity index using the Simpson index, so that bacterial dominance could be investigated in each group.

The microbial diversity index in RA and control patients showed variations. The Simpson index values of $\mathrm{C} 1, \mathrm{C} 2$, and $\mathrm{C} 3$ were $0.79,0.68$, and 0.73 , respectively. However, the Simpson index values of RA1, RA2, and RA3 were 0.63, 0.71 , and 0.65 , respectively (Table 4 ). The higher Simpson index value indicated the dominating bacterial group, so it could be inferred that several species of bacteria predominated in each RA and control patients.

Our study observed that isolate 1 dominated in $\mathrm{C} 3, \mathrm{RA} 1$, and RA2. Isolate 10 dominated in C2, RA1, and RA2, while isolate 9 dominated $\mathrm{C} 1$. Of the three isolates found in $\mathrm{C} 3$, isolate 16 was the least. This indicated that there was a competition between each isolate in $\mathrm{C} 3$, which caused the different numbers of each isolate. Differences in the abundance of isolates found in the control and RA group could also represent dysbiosis in the RA group (Table 4). 


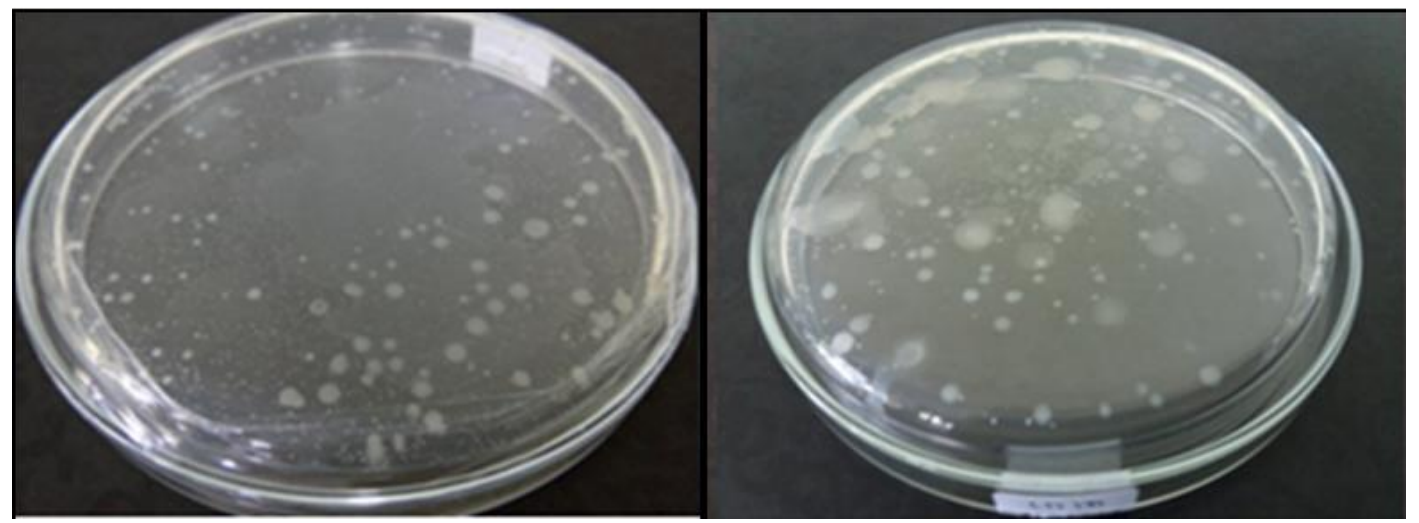

a)

b)

Figure 1. Morphology of anaerobic bacterial colonies found in fecal samples. a) Control, b) RA patient

Table 3. Morphological characterization of anaerobic bacterial colonies in fecal samples of control and RA patients

\begin{tabular}{ccccccc}
\hline Isolate & Shape & Configuration & Elevation & Optical Characteristics & Texture & Color \\
\hline $3^{*}$ & Oval & Entire & Flat & Clear & Smooth & Clear \& White \\
$7^{*}$ & Round & Entire & Flat & Clear & Smooth \\
$16^{*}$ & Round & Entire & Pulvinate & Oblique Steep & Smooth White \\
$18^{* *}$ & Round & Entire & Flat & In diameter & Smooth & Clear, Cloudy \& White \\
$1^{* *}$ & Round & Entire & Flat & Clear & Smooth & Clear \& White \\
$9 * *$ & Round & Entire & Flat & Small & Smooth & White Milk \\
$10^{* *}$ & Round & Entire & Pulvinate & Oblique & Smooth & Rough \\
$11^{* * *}$ & Irregular & Entire & Flat & Oblique & Clear \& White &
\end{tabular}

Description: $\mathrm{C}=$ control; RA= RA patient; ${ }^{*}=$ only found in control; ${ }^{*}=$ found in control and RA; ${ }^{* *}=$ only found in RA.

Table 4. Data interpretation on the level of bacterial dominance using the Simpson index in each fecal sample

\begin{tabular}{|c|c|c|c|c|c|c|}
\hline Isolate & C1 & $\mathrm{C2}$ & C3 & RA1 & RA2 & RA3 \\
\hline Isolate 1 & 5 & 12 & 124 & 248 & 52 & 27 \\
\hline Isolate 3 & 1 & 0 & 0 & 0 & 0 & 0 \\
\hline Isolate 7 & 17 & 0 & 0 & 0 & 0 & 0 \\
\hline Isolate 9 & 31 & 3 & 0 & 0 & 7 & 0 \\
\hline Isolate 10 & 2 & 19 & 0 & 207 & 56 & 17 \\
\hline Isolate 11 & 0 & 0 & 0 & 2 & 4 & 5 \\
\hline Isolate 16 & 0 & 0 & 23 & 0 & 0 & 0 \\
\hline Isolate 18 & 0 & 0 & 62 & 3 & 0 & 0 \\
\hline Id Simpson & 0.79 & 0.68 & 0.73 & 0.63 & 0.71 & 0.65 \\
\hline
\end{tabular}

Description: $\mathrm{C}=$ control; RA= RA patient

\section{$16 S$ rRNA gene analysis}

The 16S rRNA gene analysis showed that all selected isolates were successfully amplified at $200 \mathrm{bp}$ using universal primers (Fig. 2). Isolate 1 , isolate 9, and isolate 18 were identified as Enterococcus group with a band size of $300 \mathrm{bp}$. Isolate 3 , isolate 7 , and isolate 16 were Lactobacillus with a band size of $400 \mathrm{bp}$ (Fig. 2). However, isolate 10 and isolate 11 were not identified in all markers used in this study.

\section{DISCUSSION}

This study showed a significant difference in the amount of aerobic mesophilic number of microbes in the RA and control groups. The amount of aerobic mesophilic number of microbes in the RA group was higher significantly than in the control group $(P<0.01)$. Among the 3 control groups, C2 was the sample that had the highest number of microbes. It can be influenced by various factors, such as age, diet, and the disease being suffered [9]. In addition, these factors can cause dysbiosis [25]. This condition results in an imbalance amount of microbes in the digestive tract [26]. Previous studies reported a link between food protein consumption and intestinal microbiota composition based on 16S rRNA gene sequencing analysis [27]. Subjects who consumed beef food showed a reduction in the number of groups of Bifidobacterium, Bacteroides, and Clostridium 
bacteria compared with subjects who consumed meatless food [28]. It is known that consumption of peas can increase the group of Bifidobacterium and Lactobacillus bacteria, while consumption of whey protein can reduce pathogenic Bacteroides fragilis and Clostridium perfringens [29-30]. This causes the majority of researchers to reveal that protein consumption is positively correlated with microbial diversity [3032]. We assume the types of food and nutrients consumed are some of the factors that cause the diversity of microbiota composition in the intestine to change, so that it can lead to the emergence of RA disease.

Previous research revealed that the condition of dysbiosis can trigger RA disease through mucosal immune responses induced by collageninduced arthritis (CIA) [33]. The intestinal microbiota composition correlates with the overall increase in RA symptoms in CIA mice [34]. The susceptibility and severity of arthritis in some rodents kept in a germ-free environment has shown to be reduced compared to rodents induced by the $\mathrm{CIA}$ [35]. The part that plays an important role in the interaction between the host and the external environment is the surface of the mucosa, one of which is found in the digestive tract [36]. The mucous layer is continuously exposed to microorganisms that are both commensal and pathogenic [37].

The mucosal immune response is initiated through the introduction of bacterial antigens by mucosa-associated lymphoid tissue (MALT) [38]. MALT follicles containing various immunocompetent cells ( $T$ cells, B cells, and APCs) subsequently initiate an immune response [39]. In the RA condition, the barrier which becomes the defense site in the intestine is damaged [40]. This causes bacterial antigen to penetrate the mucosa. The incoming antigen can be eliminated by regulator $\mathrm{T}$ cells with specific functions [41].
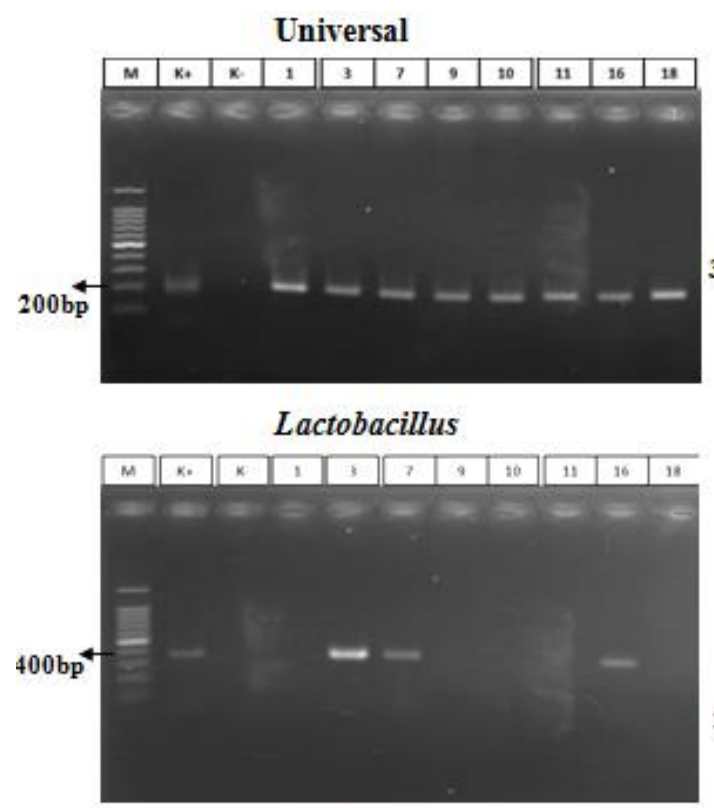

Bacteroides

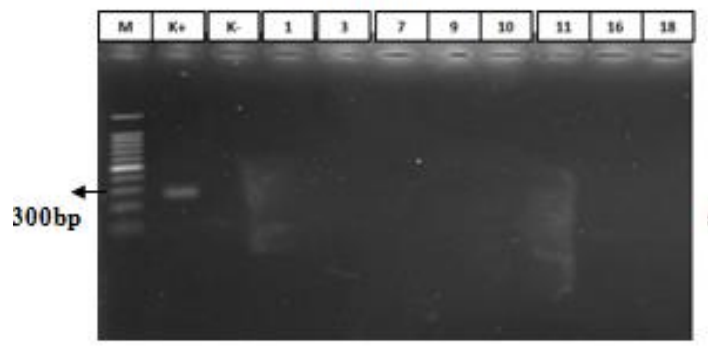

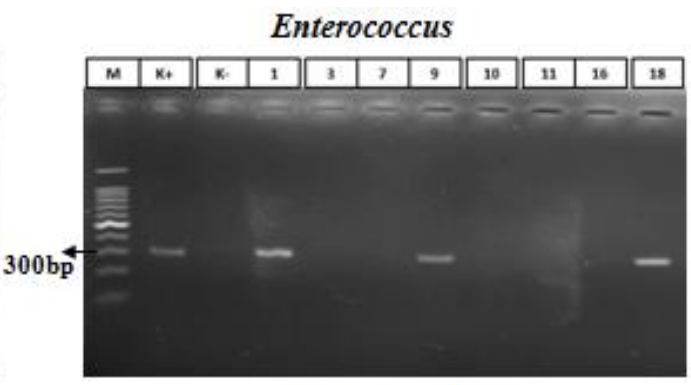

Bifidobacterium

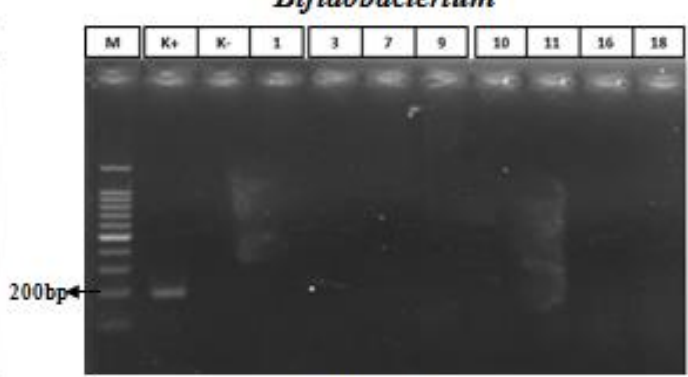

Clostridium

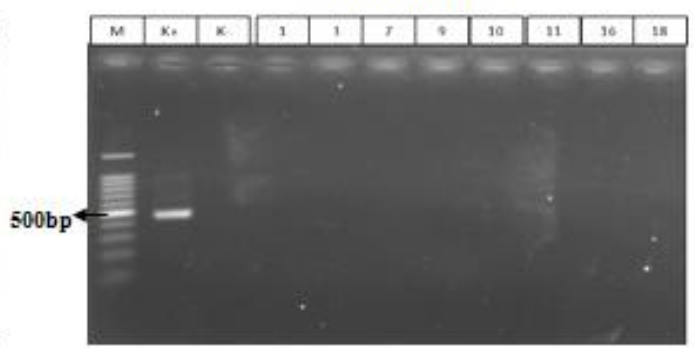

Figure 2. DNA amplification showed bacterial profiling of Universal, Enterococcus, Lactobacillus, Bifidobacterium, Bacteroides, and Clostridium. 
Table 5. Interpretation of $16 \mathrm{~S}$ rRNA PCR products in selected isolates

\begin{tabular}{|c|c|c|c|c|c|c|}
\hline Isolate & $\begin{array}{c}\text { Universal } \\
\text { Bacteria }\end{array}$ & Enterococcus & Lactobacillus & Bifidobacterium & Bacteroides & Clostridium \\
\hline & $\pm 200 \mathrm{bp}$ & $\pm 300 \mathrm{bp}$ & $\pm 400 \mathrm{bp}$ & $\pm 200 \mathrm{bp}$ & $\pm 300 \mathrm{bp}$ & $\pm 500 \mathrm{bp}$ \\
\hline Isolate 1 & + & + & - & - & - & - \\
\hline Isolate 3 & + & - & + & - & - & - \\
\hline Isolate 7 & + & - & + & - & - & - \\
\hline Isolate 9 & + & + & - & - & - & - \\
\hline Isolate 10 & + & - & - & - & - & - \\
\hline Isolate 11 & + & - & - & - & - & - \\
\hline Isolate 16 & + & - & + & - & - & - \\
\hline Isolate 18 & + & + & - & - & - & - \\
\hline
\end{tabular}

In patients with RA, dysregulation of immune system is characterized by the appearance of autoantibodies and autoreactive $T$ cells. RA patients experience dysfunction in circulating regulatory T (Treg) cells as well as an increase of T helper 17 (Th17) in synovial tissue [42]. In this case, macrophages and dendritic cells provide an environment that supports Th17 differentiation and suppresses Treg cell differentiation, which can shift T cell homeostasis toward inflammation [43]. Increasing autoantibody production triggers the formation of more proinflammatory cytokines. The secretion of proinflammatory cytokines stimulates B cells to produce antibodies [44].

One of the factors causing damage to mucosal sites is changes in diversity and abundance of microbes [45]. This triggers inflammation through an imbalance of $T$ cell subpopulations (Th1, Th2, Th17 and Treg cells) [46]. The diversity and abundance of microbes can be analyzed using the Simpson index [47]. The Simpson index analysis results indicate the presence of microbial dominance in the RA and control groups. Overall, the control group had a higher dominance value than the RA group. This showed that the types of microbes in the digestive tract of the RA group were more diverse. High bile acid concentration in the digestive tract is one of the factors that cause the diversity of bacteria. The anatomical structure of the intestine, $\mathrm{pH}$, oxygen pressure, availability of substrate and food flow rate are also the elements that lead to the diversity of bacteria in the digestive tract [48]. The data also showed that the structure of the intestinal microbiota could change periodically.

Changes in microbial diversity in the control and RA group can be evaluated through $16 \mathrm{~S}$ rRNA gene analysis using PCR. The results of the $16 S$ rRNA gene analysis showed a group of Enterococcus found in both the RA and control group (Table 5). The abundance of Enterococcus in the control group was lower than in the RA group. Enterococcus is one of the pathogenic bacteria that often causes bloodstream infections (BSI) [49]. The common species of Enterococcus found in the digestive tract are $E$. faecalis and E. faecium. However, E. faecium was reported to have a higher level of antibiotic resistance [50]. Previous studies had also found that patients with inflammatory bowel disease and rheumatoid arthritis have a high risk of being infected with E. faecium [51]. Infection by various bacteria and viruses often manifests arthritis. Other bacteria associated with infections of the digestive tract are Salmonella and Shigella, which can cause oligoarticular inflammation or polyarticular arthritis within four weeks of infection [52].

The results of this study reported that Lactobacillus bacteria dominated the control group, which was not found in the RA group. Some studies showed the opposite, where Lactobacillus was more common in RA patients than in the healthy control group [53,54]. Previous studies mentioned several species of Lactobacillus, such as L. bifidus, can cause joint swelling in mice [55]. Lactobacillus is a normal bacterial flora that has a role as a probiotic. The presence of probiotic microorganisms in the intestinal mucosal layer can prevent the presence of pathogenic bacterial colonization [56]. The presence of Lactobacillus bacteria, which acts as probiotic bacteria, causes the Enterococcus bacterial group in control patients to be found in small amounts. This bacterium has an immunoregulatory function and plays a role in maintaining intestinal microbiota homeostasis by secreting immunomodulatory agents [57]. Our study found isolate 10 in the control and RA group. Isolate 10 was not identified in all markers. Previous studies showed the presence of other bacteria that could cause inflammation, 
namely Enterobacter cloacae. E. cloacae is one of the LPS-producing gram-negative bacteria [58]. A high LPS number stimulates the inflammatory response by macrophages, which weakens the intestinal epithelial barrier triggering chronic inflammation in both rats and humans [59]. The number of pathogenic bacteria that is not offset by probiotic bacteria exacerbates damage to the intestinal epithelial barrier [60]. The loss of the Lactobacillus bacteria group in RA patients is thought to be related to competition with pathogenic bacteria. Previous studies had shown that supplementation with vegetarian foods enriched with $L$. plantarum or $L$. casei could improve health and reduce the level of inflammation in RA patients [61,62]. Therefore, it can be said that different Lactobacillus species have different effects in RA patients. It is not yet known with certainty whether RA disease is initiated by the presence of specific pathogenic bacteria [63].

Isolate 11 was the only bacteria found specifically in the RA group, which was not amplified using the primer set used in this study. Isolate 11 is not supposed to be included in the bacterial family Bacteroides, Clostridium, Bifidobacterium, Enterococcus, or Lactobacillus. Bifidobacterium, Eubacterium rectale, and Clostridium coccoides bacterial groups were reported to decrease in RA patients [64]. Moreover, the Bacteroides in the RA group also decreased [65]. Several studies also revealed the presence of other bacteria associated with RA morbidity, including Mycoplasma fermentans [66], E. coli [67], and Proteus mirabilis [68], so that further research is needed to determine the family of bacterial isolate 11 .

\section{CONCLUSION}

This study found that Enterococcus was the bacterial group found in abundance in the control (Non-RA) and RA patients in Malang. The abundance of Enterococcus in RA patients was higher than in the control patients. The bacterial group in control patients was dominated by the Lactobacillus bacteria, which was not found in the RA patients. The diversity of Lactobacillus species can have positive (symbiotic) effects that inhibit the presence of Enteroccocus bacteria in RA patients. Further analysis is required to determine the bacterial group of isolate 11 in the RA patients.

\section{ACKNOWLEDGEMENT}

This study was supported by the Institute of Research and Community Service (LPPM)
Brawijaya University No: 696. 101/UN10.C10/PN /2019. We thank the Biosains institute of Brawijaya University and Microbiology Laboratory of Brawijaya University for providing laboratory equipment and facilities.

\section{REFERENCES}

[1] Maeda, Y., K. Takeda. 2017. Role of gut microbiota in rheumatoid arthritis. J. Clin. Med. 6(60). 1-7.

[2] RISKESDAS. 2013. Hasil Utama Riskesdas 2013. Available at: www.depkes.go.id.

[3] RISKESDAS. 2018. Hasil Utama Riskesdas 2018. Available at: www.depkes.go.id.

[4] Ciccia, F., A. Ferrante, G. Guggino, G. Triolo. 2016. The role of the gastrointestinal tract in the pathogenesis of rheumatic diseases. Best Pract. Res. Clin. Rheumatol. 30. 889900.

[5] Panebianco, C., A. Andriulli, V. Pazienza. 2018. Pharmacomicrobiomics: Exploiting the drug-microbiota interactions in anticancer therapies. J. Microbiome. 6(1). 92.

[6] Asquith, M., D. Elewaut, P. Lin, J.T. Rosenbaum. 2014. The role of the gut and microbes in the pathogenesis of spondyloarthritis. Best Pract. Res. Clin. Rheumatol. 28. 687-702.

[7] Venuturupalli, S. 2017. Immune mechanisms and novel target in Rheumatoid arthritis. Immunol. Allergy Clin. North Am. 37(2):301-313.

[8] Rosestein, E.D., R.A. Greenwald, L.J. Kushner, G. Weissmann. 2004. Hyphothesis: the humoral timmune respone to oral bacteria provides a stimulus for the development of rheumatoid arthritis. J. Inflamm. 28(6). 311-318.

[9] Rinninella, E., P. Raoul, M. Cintoni, F. Franceschi, G. Migggiano. 2019. The 4-H of Biomarkers in arthritis: a lot of help, occasional harm, some hype, increasing hope. J. Rheumatol. 46(7). 758-763.

[10] Anderson, J., L. Caplan, J. Yazdany, M.L. Robbins, T. Neogi, K. Michaud, K. G. Saag, J.R. O'del, S. Kazi. 2012. Rheumatoid arthritis disease activity measures: American collage of rheumatology recommendations for use in clinical practice. J. Arthritis Care Res. 65(5). 640647.

[11] Maslowski, K.M., A.T. Vieira, A. Ng, J. Kranich, F. Sierro, D. Yu, et al. 2009. Regulation of inflammatory responses by 
gut microbiota and chemoattractant receptor GPR43. J. Nature. 461. (7268). 1282-6.

[12] Rogier, R., M.I. Koenders, S. AbdollahiRoodsaz. 2015. Toll-like receptor mediated modulation of $T$ cell response by commensal intestinal microbiota as a trigger for autoimmune arthritis. J. Immunol. 1-9.

[13] Stecher, B., W.D. Hardt. 2011. Mechanisms controlling pathogen colonization of the gut. Curr. Opin. Microbiol. 14. 82-91.

[14] Diamanti, A. P., M.M. Rosado, R. D'Amelio. 2018. Infectious agents and inflammation: The role of microbiota in autoimmune arthritis. J. Front. Microbiol. 8 (2696). 1-9.

[15] Rodriguez, J.P.L., R.E.M. Martines, C.A. Mendoza, N.P. Marin, G.J. Seymour. 2010. Rheumatoid arthritis and the role of oral bacteria. J. Oral Microbiol. 2(5784). 1-9.

[16] Zhang, X., D. Zhang, H. Jia, Q. Feng, D. Wang, D. Liang, et al. 2015. The oral and gut microbiomes are perturbed in rheumatoid arthritis and partly normalized after treatment. Nat. Med. 21(8). 895-905.

[17] Matysik, S., C.I.L. Roy, G. Liebisch, S.P. Claus. 2016. Metabolomics of fecal samples: a practical consideration. Trend in Food Science and Technology. 57. 244-255.

[18] Usami, M., M. Miyoshi, Y. Kanbara, M. Aoyama, H. Sakaki, K. Shuno, K. Hirata, M. Takahashi, K. Ueno, Y. Hamada, S. Tabata, T. Asahara, K. Nomoto. 2013. Analysis of fecal microbiota, organic acids and plasma lipids in hepatic cancer patients with or without liver cirrhosis. J. Clin. Nutr. 32. 444451.

[19] Guinness, P., B. Walpole. 2015. Environmental systems and societies for the IB diploma coursebook. Cambridge University Press. USA.

[20] Shaheen, H., D. M. Harper, S.M. Khan, Z. Ullah. 2011. Species diversity, community structure and distribution patterns in westen Himalayan alpine pastures of Kashmir, Pakistan. Mt Res. Dev. 31(2). 153159.

[21] Fatchiyah., E.L. Arumingtyas, S. Widyarti, S. Rahayu. 2011. Biologi molekuler prinsip dasar analisis. Erlangga. Jakarta

[22] Yusuf. F., S. Ilyas, H.A.R. Damanik, Fatchiyah. 2016. Microbiota composition, HSP70 and Caspase-3 expression as marker for colorectal cancer patients in Aceh,
Indonesia. The Indonesian Journal of Internal Medicine. 48. (4). 289-299.

[23] Vanhoutte T., G. Huys, E.D. Brandt, J. Swings. 2004. Temporal stability analysis of the microbiota in human feses by denaturing gradient gel electrophoresis using universal and group-spesific 16S rRNA gene primers. FEMS Microbiol. Ecol. 48(3). 437-46.

[24] Maukonen J., J. Matto, R. Satokari, H. Soderlund, T. Mattila-Sandholm, M. Saarela. 2006. PCR DGGE and RTPCR SGGE show diversity and short-term temporal stability in the Clostridium cocoidesEubacterium rectal group in the human intestinal microbiota. FEMS Microbiol. Ecol. 58. 517-28.

[25] Murphy, R., A.W. Stewart, I. Braithwaite, R. Beasley, R.J. Hancox, E.A. Mitchell. 2014. The ISAAC phase three study group: Antibiotic treatment during infancy and increased body mass index in boys: an international cross-sectional study. Int. J. Obes. (Lond). 38(8). 1115-1119.

[26] Round, J.L., S. K. Mazmanian. 2009. The gut microbiome shapes intestinal immune responses during helath and disease. J. Nat. Rev. Immunol. 9(5). 313-323.

[27] Conlon, M.A., A.R. Bird. 2015. The impat of diet and lifestyle on gut microbiota and human health. Nutrients. 7. 17-44.

[28] Singh, R.K., H.W. Chang, D. Yan, K.M. Lee, D. Ucmak, K. Wong, M. Aabrouk, B. Farahnik, M. Nkamura, T.H. Zhu, T. Bhutani, W. Liao. 2017. Influence of diet on the gut microbiome and implications for human health. J. Transl. Med. 15 (73).1-17.

[29] Cotillard, A., S.P. Kennedy, L.C. Kong, E. Prifti, N. Pons, E. Le Chatelier, et al. 2013. Dietary intervention impact on gut microbial gene richness. Nature. 500. 585578.

[30] Dominika, S., N. Arjan, R.P. Karyan, K. Henryk. 2011. The study on the impact of Glycated pea protein on human intestinal bacteria. Int. J. Food Microbiol. 145. 267-72.

[31] David, L.S., C.F. Maurice, R.N. Carmody, D.B. Gootenberg, J.E. Button, B.E. Wolfe, et al. 2014. Diet rapidly and reproducibly alters the human gut microbiome. Nature. 505. 559-63.

[32] Clarke, S.F., E.F. Murphy, O. O’Sullivan, A.J. Lucey, M. Humpreys, A. Hogan, et al. 2014. Exercise and associated dietary extremes 
impact on gut microbial diversity. J. Gut. 63. 1913-1920.

[33] Jubair, W.K., J.D. Hendrickson, E.L. Severs, H.M. Schulz, S.I.D. Adhikari, J.D. Pagan, et al. 2018. Modulation of inflammatory arthritis in mice by gut microbiota through mucosal inflammation and autoantibody generation. J. Arthritis Rheumatol. 70(8). 1220-1233.

[34] Xiao, M., X. Fu, Y. Ni, J. Chen, S. Jian, Wang, L. Li, G. Du. 2018. Protective effects of Paederia scandens extract on rheumatoid arthritis mouse model by modulating gut microbiota. J. Ethnopharmacol. 226. 97104.

[35] Liu, X., B. Zeng, J. Zhang, W. Li, F. Mou, H. Wang, Q. Zou, B. Zhong, L. Wu, H. Wei, Y. Fang. 2016. Role of the gut microbiome in modulating arthritis progression in mice. J. Sci. Rep. 6. 30594.

[36] Mankia, K., P. Emery. 2015. Is localized autoimmunity the trigger for rheumatoid arthritis? Unravelling new targets for prevention. J. Discov. Med. 20. 129-135.

[37] Artis, D. 2008. Epithelial-cell recognition of commensal bacteria and maintenance of immune homeostasis in the gut. Nat. Rev. Immunol. 8. 411-420.

[38] Williams A., T. Hussell, C. Lloyd. 2012. Immunology: mucosal and body surface defences. WileyBlackwell. Chichester, West Sussex; Hoboken, NJ.

[39] Tjärnlund A. 2005. Does IgA play a role in protection against pulmonary tuberculosis?. Stockholm University. Sweden.

[40] Hatakka, K., J. Martio, M. Korpela, M. Herranen, T. Poussa, T. Laasanen, M. Saxelin, H. Vapaatalo, E. Moilanen, R. Korpela. 2003. Effects of probiotic therapy on the activity and activation of mild rheumatoid arthritis-a pilot study. Scand. J. Rheumatol. 32. 211-215.

[41] Mayer A.K., A.H. Dalpke. 2007. Regulation of local immunity by airway epithelial cells. Archivum Immunologi at Therapiae Experimentalis. 55. 6. 353-62.

[42] Scher, J.U., S.B. Abramson. 2011. The microbiome and rheumatoid arthritis. Nat. Rev. Rheumatol. 7. 569-578.

[43] Mcllnnes, L.B., G. Schett. 2011. The pathogenesis of rheumatoid arthritis. N Engl. J. Med. 365. 23. 1-15.

[44] Lourido, L., F.J. Blanco, C. Ruiz-Romero. 2017. Defining the proteomic landscape of rheumatoid arthritis: progress and prospective clinical applications. Expert Rev. Proteomics. 14. 431-444.

[45] Holers, V.M. 2013. Autoimmunity to citrullinated proteins and the initiation of rheumatoid arthritis. Curr. Opin. Immunol. 25. 728-735.

[46] Lee, N., W.U. Kim. 2017. Microbiota in T-cell homeostasis and inflammatory diseases. Exp. Mol. Med. 49(340). 1-10.

[47] Morris, E.K., T. Caruso, F. Buscot, M. Fischer, C. Hancock, T.S. Maier, T. Meiners, C. Muller, E. Obermainer, D. Prati. 2014. Choosing and using diversity indices: insights for ecological applications from the german biodiversity exploratories. J. Ecol. Evol. 4(18). 3514-3524.

[48] Flint, H.J., K.P. Scott, P. Louis, S.H. Duncan. 2012. The role of the gut microbiota in nutrition and health. Nat. Rev. Gastroenterol. Hepatol. 9. 577-589.

[49] Pien, B.C., P. Sundaram, N. Raoof, S.F. Costa, S. Mirrett, C.W. Woods, L.B. Reller, M.P. Weinstei. 2010. The clinical and prognostic importance of positive blood culturesin adults. Am. J. Med. 123. 819828.

[50] McBride, S.J., A. Upton, S.A. Roberts. 2010. Clinical characteristics and outcomes ofpatients with vancomycin-susceptible Enterococcus faecalis and Enterococcus faecium bacteraemia - a five-year retrospective review. Eur. J. Clin. Microbiol. Infect. Dis. 29. 107-114.

[51] Billington, E.O., S.H. Phang, D.B. Gregson, J.D.D. Pitout, T. Ross, D.L. Church, K.B. Laupland, M.D. Parkins. 2014. Incidence, risk factors, and outcomes for Enterococcus spp. Stream infections: a population-based study. Int. J. Infect. Dis. 26. 76-82.

[52] Becker J., K.L. Winthrop. 2010. Update on rheumatic manifestations of infectious diseases. Curr. Opin. Rheumatol. 22. 72-77.

[53] Liu, X., Q. Zou, B. Zeng, Y. Fang, H. Wei. 2013. Analysis of fecal Lactobacillus community structure in patients with early rheumatoid arthritis. J. Curr. Microbiol. 67. 170-176.

[54] Van de Wiele T., J.T. van Praet., M. Marzorati., M.B. Drennan, D. Elewaut. 2016. How the microbiota shapes rheumatic diseases. Nat. Rev. Rheumatol. 12. 398-411.

[55] Abdollahi-Roodsaz S., L.A.B. Joosten, M.I. Koenders, I. Devesa, M.F. Roelofs, T. Radstake, et al. 2008. Stimulation of TLR2 
and TLR4 differentially skews the balance of T cells in a mouse model of arthritis. J. Clin. Invest. 118(1). 205-216.

[56] M.V.P. Leão, R.C. Cassia, S.S.F. Dos Santos, C.R.G.E. Silva, A.O.C. Jorge. 2011. Influence of consumption of probiotics on presence of Enterobacteria in the oral cavity. Braz. Oral Res. 25(5). 401-406.

[57] Mortha, A., A. Chudnovskiy, D. Hashimoto, M. Bogunovic, S.P. Spenver, Y. Belkaid, M. Merad. 2014. Microbiota dependent crosstalk between macrophages and ILC3 promotes intestinal homeostatis. Science. 343. 1249-288.

[58] Moreira A.P., T.F. Texeira, A.B. Ferreira, C. PeluzioMdo, C. AlfenasRde. 2012. Influence of a high-fat diet on gut microbiota, intestinal permeability and metabolic endotoxaemia. Br. J. Nutr. 108. 801-809.

[59] Lim, S.M., J.J. Jeong, K.H. Woo, M.J. Han, D.H. Kim. 2015. Lactobacillus sakei OK67 ameliorates high-fat diet-induced blood glucose intolerance and obesity in mice by inhibiting gut microbiota lipopolysaccharide production and inducing colon tight junction protein expression. Nutr. Res. 36. 337-348.

[60] Guarner, F., A.G. Khan, J. Garisch, R. Eliakim, A. Gangl, A. Thomson, et al. 2012. World gastroenterology organisation global guidelines: probiotics and prebiotics. J. Clin. Gastroenterol. 46. 468-481.

[61] Pineda, M.A., M.A. McGrath, P.C. Smith, L. AlRiyami, J. Rzepecka., J.A. Gracie, W. Harnett, M.M. Harnett. 2012. The parasitic helminth product ES-62 suppresses pathogenesis in collagen-induced arthritis by targeting the interleukin- 17-producing cellular network at multiple sites. Arthritis and Rheum. 64(10). 3168-3178.

[62] Alipour, B., A. Homayouni-Rad, E. VaghefMehrabany, S.K. Sharif, L. Vaghef Mehrabany, M. Asghari-Jafarabadi, M.R. Nakhjavani, J.M. Nia. 2014. Effects of Lactobacillus casei supplementation on disease activity and inflammatory cytokines in rheumatoid arthritis patients: a randomized double-blind clinical trial. Int. J. Rheum. Dis. 17. 519-527.

[63] Scher, J.U., V. Joshua, A. Artacho, S.A. Roodsaz, J. Ocknger, S. Kullberg, et al. 2016. The lung microbiota in early rheumatoid arthritis and autoimmunity. J. Microbiome. 4(60). 1-10.
[64] Seksik, P., L. Rigottier-Gois, G. Gramet, M. Sutren, P. Pochart, P. Marteau, R. Jian, J. Doré. 2003. Alterations of the dominant faecal bacterial groups in patients with Crohn's disease of the colon. J. Gut. 52(2). 237-242.

[65] Maeda, Y., T. Kurakawa, E. Umemoto, D. Motooka, Y. Ito, K. Gotoh, et al. 2016. Dysbiosis contributes to arthritis development via activation of autoreactive $\mathrm{T}$ cells in the intestine. J. Arthritis Rhematol. 68. 2646-2661.

[66] Sato, N., T. Oizumi, M. Kinbara, T. Sato, H. Funayama, S. Sato, K. Matsuda, H. Takada, S. Sugawara, Y. Endo. 2010. Promotion of arthritis and allergy in mice by aminoglycoglycerophospholipid, a membrane antigen specific to Mycoplasma fermentans. FEMS Immunol. Med. Microbiol. 59. 33-41.

[67] Newkirk, M.M., A. Zbar, M. Baron, A.R. Manges. 2010. Distinct bacterial colonization patterns of Escherichia coli subtypes associate with rheumatoid factor status in early inflammatory arthritis. J. Rheumatol. 49. 1311-1316.

[68] Ebringer, A., T. Rashid, C. Wilson. 2010. Rheumatoid arthritis, Proteus, anti-CCP antibodies and Karl Popper. J. Autoimmun. Rev. 9. 216-223. 